\title{
Denoised VEGFR2 expression relates to sunitinib efficacy in advanced Clear Cell Renal Cell Carcinoma
}

\author{
Loïc Verlingue ${ }^{1,2,3^{*}}$, Daphné Morel ${ }^{1,2,4}$, Mickaël Schaeffer ${ }^{3,5}$, Laurent Tanguy ${ }^{3,6}$, Jordane Schmidt ${ }^{7}$, \\ Jean-Christophe Bernhard ${ }^{8,9}$, Bertrand Loubaton ${ }^{3}$, Dominique Bagnard ${ }^{3,7^{*}}$ \\ ${ }^{1}$ Drug Development Department (DITEP), Gustave Roussy Cancer Campus, 114 rue Edouard Vaillant, 94800 \\ Villejuif, France; \\ ${ }^{2}$ University Paris-Saclay, France; \\ ${ }^{3}$ Adaptherapy, 650 boulevard Gonthier d'Andernach, 67400 Illkirch-Graffenstaden, France; \\ ${ }^{4}$ Radiation oncology Department, Gustave Roussy Cancer Campus, 114 rue Edouard Vaillant, 94800 Villejuif, \\ France; \\ ${ }^{5}$ Alstats, $2 \mathrm{~A}$ rue de Bruxelles, Sélestat, France; \\ ${ }^{6}$ L. Tanguy 9, rue de verdun 29200 Brest; France \\ ${ }^{7}$ INSERM U1119 BMNST Lab, Labex Medalis, Fédération de Médecine Translationnelle de Strasbourg, Pôle \\ API, 300 boulevard Sébastien Brant, 67412 Illkirch-Graffenstaden, France; \\ ${ }^{8}$ Department of Urology - CHU Bordeaux, France \\ ${ }^{9}$ French Research network on Kidney Cancer UroCCR, CHU Bordeaux, France; \\ *Corresponding authors: Loic Verlingue, loic.verlingue@gustaveroussy.fr
}

\section{ABSTRACT}

Short summary:_Personalized biomarkers can facilitate decision making upon multiple therapeutic options in ccRCC. VEGFR2 expression denoised with 37 normal and tumor gene-expressions relates to sunitinib effect whereas raw VEGFR2 expression doesn't relate to sunitinib effect.

Background: Several studies suggested that molecular analysis of patients with advanced clear cell renal cell carcinoma (ccRCC) could indicate whether a patient is susceptible of benefiting from sunitinib in first-line systemic treatment compared to immunotherapies. However, data remain conflicting and no predictive biomarker is validated so far to decipher if sunitinib could still represent a good therapeutic option in first line setting and beyond.

Methods: PREDMED ${ }^{\circledR}$ denoised the tumor RNA expression of 37 genes including KDR (encoding VEGFR2) estimated by RT-qPCR, by normalizing it on the expression of normal kidney tissue and cell types. We investigated the performance of PREDMED ${ }^{\circledR}$ VEGFR2-scoring to predict the clinical effect of sunitinib for patients affected by ccRCC.

Results: Among the 34 ccRCC patients' samples retrospectively retrieved from the UroCCR project (NCT03293563), high VEGFR2 scores were associated with objective clinical responses under sunitinib treatment and low scores with stable disease or progression with a sensitivity of $86 \%$, a specificity of $67 \%$ and an AUC of $72.5 \%$ (95\% CI[50.1-94.9]; p=0.04). VEGFR2 scores were significantly and positively related to progression-free survival $(\mathrm{HR}=0.465 ; 95 \% \mathrm{CI}[0.221-0.978]$; $\mathrm{p}=0.0311)$ and overall survival $(\mathrm{HR}=0.400 ; 95 \% \mathrm{CI}[0.192-0.834] ; \mathrm{p}=0.0134)$ under sunitinib treatment. In our cohort, raw VEGFR2 expression (before PREDMED ${ }^{\circledR}$ processing) was not related to the above mentioned outcomes.

Conclusion: We describe a gene-expression based algorithm that is accurately related to the effect of sunitinib for patients with ccRCC. We further plan a validation of PREDMED ${ }^{\circledR}$ for combinatorial strategies involving antiangiogenics and immune-checkpoint blockers.

Keywords: gene expression, clear cell renal cell carcinoma, personalized treatment, medical device, biomarker, sunitinib 
medRxiv preprint doi: https://doi.org/10.1101/2021.11.10.21266155; this version posted November 10, 2021. The copyright holder for this preprint (which was not certified by peer review) is the author/funder, who has granted medRxiv a license to display the preprint in perpetuity.

All rights reserved. No reuse allowed without permission.

Gene expression signature to predict the response to sunitinib in advanced ccRCC

\section{INTRODUCTION}

Renal cell carcinoma (RCC) corresponds to $85 \%$ of all kidney cancer, with clear cell renal cell carcinoma (ccRCC) being the most frequent subtype accounting up to $80 \%$ of all RCC ${ }^{1}$. The molecular characterization of sporadic ccRCC is highly specific, with the Von Hippel-Lindau (VHL) gene being altered or epigenetically silenced in more than $90 \%$ of the cases ${ }^{2,3}$. The loss of VHL leads to the stabilization of hypoxia inducible factors (HIF$1 \alpha$ and HIF-2 $\alpha$ ), stimulating the production of oncogenic and pro-angiogenic agents such as VEGF and PDGF ${ }^{4,5}$ that drive the majority of ccRCC and is efficiently targeted using antiangiogenics.

CcRCC often remains asymptomatic for several years and more than half of ccRCC are diagnosed incidentally ${ }^{6}$, typically at an advanced stage. The management of advanced and metastatic ccRCC mostly relies on systemic treatments according to a risk stratification that split patients into good-, intermediate- and poor-prognosis groups following International Metastatic RCC Database Consortium (IMDC criteria) ${ }^{7,8}$. In the past few months, clinical practice guidelines drastically evolved to propose as the preferred first-line regimen PD-1 inhibitor (pembrolizumab or nivolumab) for all riskgroups patients, combined or not with an antiangiogenic (axitinib) or CTLA-4 inhibitor (ipilimumab). Though, sunitinib and pazopanib - both antiangiogenic multikinases - still represent recommanded therapeutic alternative options for first-line systemic treatment, for example for patients ineligible or unwiling to receive immune-checkpoint blockers (NCCN Guidelines for Kidney Cancer, version 1.2021 - July 15, 2020).

Some pivotal trials demonstrated the clinical superiority of immune-checkpoint inhibitors used in combination over monotherapies of anti-angiogenics in first-line setting in unselected patients ${ }^{9,10}$. However, several studies suggested that some patients might benefit more from a monotherapy of antiangiogenic in first line than from immune- checkpoint blockers, combined or not with antiangiogenics, based on their tumoral molecular profiling. For example, Liu et al. reported that PBRM1 loss-of-function - which is found in $40 \%$ of $\mathrm{ccRCC}^{3}$ - was associated with an upregulated angiogenesis and a less immunogenic microenvironement, and therefore patients with PBRM1-mutated ccRCC were more likely to benefit from firstline sunitinib than an immune-checkpoint blocker ${ }^{11}$. These findings were consistent with the results of the prospective IMmotion150 trial that reported improved survival outcomes following sunitinib compared to atezolizumab (anti-PDL1) with or without bevacizumab in molecularly selected patients, based on a gene expression signature of 7 VEGF-inducible angiogenesis-associated genes ${ }^{12}$. However, the correlation between expression of VEGF or VEGF-related proteins and response to sunitinib remains unclear and conflicting data limit its application in the clinic ${ }^{13-16} 17,18$.

In this study, we explored the clinical performance of a method to denoise the analysis of VEGFR2 expression in ccRCC Formalin-Fixed Paraffin-Embedded (FFPE) samples, based on a 37 gene-expression signature from the tumor and normal kidney cells. We evaluated if VEGFR2 scores could predict objective responses and outcomes of patients with advanced or metastatic ccRCC treated with sunitinib in first-line, second-line or third-line.

\section{MATERIALS AND METHODS}

\subsection{Data collection and patient selection}

Patients were retrospectively retrieved from the UroCCR project (French research network on kidney Cancer - NCT03293563). Eligible patients were 18 years of age or older, had a primary or recurrent ccRCC treated with sunitinib in any treatment line setting, with available material from surgical resection of the primary tumor prior to sunitinib treatment. Patients were excluded from the analysis in case of missing clinical data or RNA Integrity Number (RIN) below 7. 
medRxiv preprint doi: https://doi.org/10.1101/2021.11.10.21266155; this version posted November 10, 2021. The copyright holder for this preprint (which was not certified by peer review) is the author/funder, who has granted medRxiv a license to display the preprint in

Outcomes collected were the RECIST V1.1 best response: complete or partial response (CR or PR, respectively), stable disease (SD) or progressive disease (PD); PFS in months (calculated as the time from the first intake of sunitinib to the date of first documented progression or death); OS in months (calculated as the time from the first intake of sunitinib to the date of death from any cause); duration of follow-up; number and type of previous treatment lines. Objective response rate (ORR) was defined as the proportion of patients with CR or PR under sunitinib ${ }^{19}$. Additional clinical characteristics available comprised: age at diagnosis, gender, African phenotype ethnicity (yes/no), number and type of previous lines of treatment and the type of surgery (cytoreductive of complete nephrectomy).

\subsection{Study objectives}

The primary objective was to evaluate the relation between PREDMED® VEGFR2scores and the effect of sunitinib, represented by ORR and PFS, for patients with advanced or metastatic ccRCC. The secondary objective was to evaluate the relation between PREDMED ${ }^{\circledR}$ VEGFR2-scores and OS. Performance estimation relied on sensitivity, specificity and Receiver Operating Characteristic Area Under the Curve (AUC), as specified by the STARD 2015 guidelines ${ }^{20}$.

\subsection{PREDMED Medical Device}

\subsubsection{Rationale}

PREDMED ${ }^{\circledR}$ is an in vitro diagnostic multivariate index assay (IVDMIA) that normalizes the RNA expression of 37 selected genes from tumor samples on a bank of normal tissues and cells' gene expressions. The algortihm provides a score for each gene, ranked from 0 to 1000 , that reflects their relative dysregulations compared to normal values, as previously described ${ }^{21}$.

The provisional limited panel of 37 genes was selected based on current knowledge of mainly targetable biological mechanisms implicated in ccRCC, comprising the tumor cells, stromal cells, vessels and immune cells. (listed in Fig. 1). For the current study we prospectively choosed to use the VEGFR2-score only.

\subsubsection{Samples and biological methods}

CcRCC FFPE samples (CRB-K - CHU Bordeaux) were all processed in a centralized laboratory in Strasbourg, France (INSERM U1119, BMNST Lab, University of Strasbourg, Labex Medalis, Fédération de Médecine Translationnelle). Blocks were stored at $-20^{\circ} \mathrm{C}$ and RNA samples were stored at $-80^{\circ} \mathrm{C}$ following extraction. Total RNA was extracted with TRI Reagent ${ }^{\circledR}$ solution (Molecular Research Center; \#TR118), quantified, assessed for quality (RIN) and reverse transcribed (Applied Biosystems; \#4368814). The obtained cDNA was diluted to get a final concentration of $1 \mu \mathrm{g} / 100 \mu \mathrm{L}$. RTqPCR was performed using TaqMan Gene expression Master Mix (Applied Biosystems; \#4369016). Experiments were conducted using customized microplates specially designed for this project by Applied Biosystems (Custom TaqMan Array Plates; \#4391526) to contain human specific TaqMan $^{\circledR}$ probes at $1 \mathrm{X}$ and primers at 1X (list provided in Suppl Fig. 1).

\subsubsection{Analytical methods / PREDMED® algorithm}

PREDMED® normalization method has been previously described ${ }^{21}$. Briefly, the reference panel gene expressions were assessed using a cocktail of non-tumoral kidney tissues which comprised: whole normal kidney total RNA (\#AM7976), medullary kidney RNA (CRB-K CHU Bordeaux), cortical kidney RNA (CRB$\mathrm{K}$ - CHU Bordeaux), human renal glomerular endothelial cell total RNA (\#4005-SC), human renal proximal tubular epithelial cell total RNA (\#4105-SC), human renal cortical epithelial cell total RNA (\#4115-SC), human renal epithelial cell total RNA (\# 4125-SC), human renal mesangial cell total RNA (\#4205-SC), and a low grade carcinoma of kidney total RNA (\# CR559126).

Then, to reduce interindividual variability and allow the normalization process on the reference panel, gene expressions were first normalized on the mean expression of two 
medRxiv preprint doi: https://doi.org/10.1101/2021.11.10.21266155; this version posted November 10, 2021. The copyright holder for this preprint (which was not certified by peer review) is the author/funder, who has granted medRxiv a license to display the preprint in

Gene expression signature to predict the response to sunitinib in advanced ccRCC

housekeeping genes (18S ribosomal RNA and Glyceraldehyde 3-phosphate dehydrogenase $G A P D H)$, as follow: $\triangle \mathrm{Ct}$ (gene) $=\mathrm{Ct}$ (gene) mean $\mathrm{Ct}$ (housekeeping genes). $2^{-\Delta \mathrm{Ct}(\text { gene })}$.

Following similar normalization steps, run multiple times, the resulting score ranged from 0 to 1000 for each gene: 1000 corresponding to the highest relative upregulation from normal. PREDMED ${ }^{\circledR}$ is protected by International Application patent PCT/EP2016/078353.

\subsection{Statistical analysis}

All recorded variables were described by using position and dispersion statistics, such as mean, median and 95\% confidence interval $(95 \% \mathrm{CI})$. The assumption of normality (defined by the Gaussian distribution) was tested by the Shapiro Wilk test on each quantitative variable distribution. To compare survival distributions, we used the log-rank Mantel-Cox test, and described the results with the Hazard Ratio, 95\%CI ratio and associated p-value. All statistical tests were two-tailed and a p-value $<0.05$ was considered as statistically significant. All analyses were performed using $\mathrm{R}$ software under its version 3.1 and JAGS for the MCMc estimations in Bayesian models ${ }^{22}$. Except for ROC curves generated using $\mathrm{R}$, all graphs were created using GraphPad Prism ${ }^{\circledR}$ V8.0.2.

\subsection{Ethics}

The trial was conducted in accordance with the local Good Clinical Practice guidelines (CNIL number declaration 2005853 v 0, DC-20173040). The biobank biological resource center number associated with this study is BB-003300036. The UroCCR project (NCT03293563) obtained the authorization number DR-2013206 from the national information science and liberties commission (CNIL) and all patients included consented to the use of their personal and genetic data.

\section{RESULTS}

\subsection{Patients' characteristics}

We retrospectively collected 46 FFPE tumor samples from patients addressed for advanced or metastatic ccRCC between December, 2006 and February, 2016 (Fig. 1). Among these 46 patients, 5 patients were excluded from the analysis: 2 patients received sunitinib before surgical resection, 1 patient never received sunitinib and 2 patients had missing clinical data. Gene expressions were assessed by RTqPCR and led to the exclusion of 7 patients due to poor RNA quality. Altogether, 34 patients remained (Fig. 2). The median age was 66 years old and the sex ratio approximately 3 males for 1 woman (Table 1). The majority of patients $(\mathrm{N}=30,88.2 \%)$ had a ccRCC at a metastatic stage at the time of study and 31 (91.2\%) patients received sunitinib as first-line systemic treatment.

In our cohort, sunitinib treatment was associated with an overall objective response rate of $20.6 \%$, including 1 complete response $(2.9 \%)$ and 6 partial responses (17.6\%). Nine patients $(26.5 \%)$ progressed and 18 patients (52.9\%) harbored stable disease as best response. After a median follow-up of 24.7 months, median PFS was 7.8 months and median OS was 20.2 months, which is similar to data from pivotal trials that evaluated sunitinib in the first-line setting ${ }^{9,10}$. At the time of end of study, 5 patients were still alive, 2 of them still under sunitinib treatment. 
medRxiv preprint doi: https://doi.org/10.1101/2021.11.10.21266155; this version posted November 10,2021 . The copyright holder for this preprint (which was not certified by peer review) is the author/funder, who has granted medRxiv a license to display the preprint in

Gene expression signature to predict the response to sunitinib in advanced ccRCC

\begin{tabular}{c}
\hline Genepanel \\
\hline ABL1 \\
AKT1 \\
ALK \\
AR \\
BCL2 \\
BRAF \\
CDK4 \\
CDK6 \\
EGFR \\
ERBB2 \\
ERBB3 \\
FGFR1 \\
FGFR2 \\
FGFR3 \\
FLT4 \\
HDAC1 \\
HDAC2 \\
HIF1A \\
IGF1R \\
ITGA5 \\
JAG1 \\
KDR (VEGFR2) \\
KIR2DL5 \\
MAP2K1 \\
MAP2K2 \\
MDM2 \\
MET \\
MMP9 \\
PDGFRA \\
PDGFRB \\
PIK3R1 \\
PROM1 \\
RAF1 \\
RET \\
VEGFA \\
\hline Housekeeping \\
\hline 18S \\
GAPDH \\
\hline
\end{tabular}

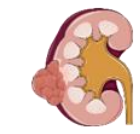

ccRCC sample

Patient 1

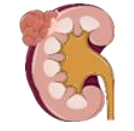

cCRCC sample

Patient 2

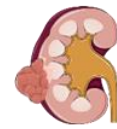

cCRCC sample

Patient 3

\section{RT-qPCR of target gene RNA expressions}

Normalization on housekeeping gene expressions Normalization on non-tumoral tissue Iterations Ranking

\section{Personalized report}

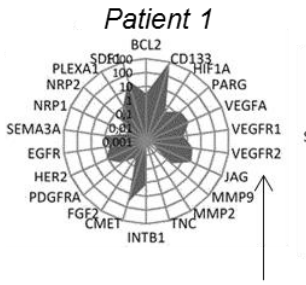

VEGFR2 low-score
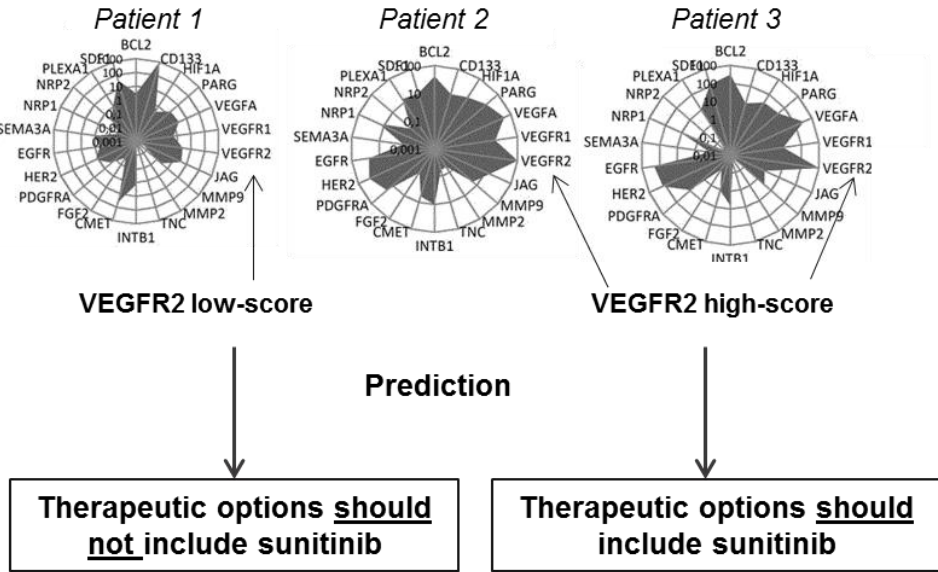

Figure 1: Summary of PREDMED method. PREDMED normalizes the RNA expression of 37 genes from tumor samples on a bank of normal tissues and cells' gene expressions. The algortihm provides a score for each gene, ranked from 0 to 1000, that reflects their relative dysregulations compared to normal values.

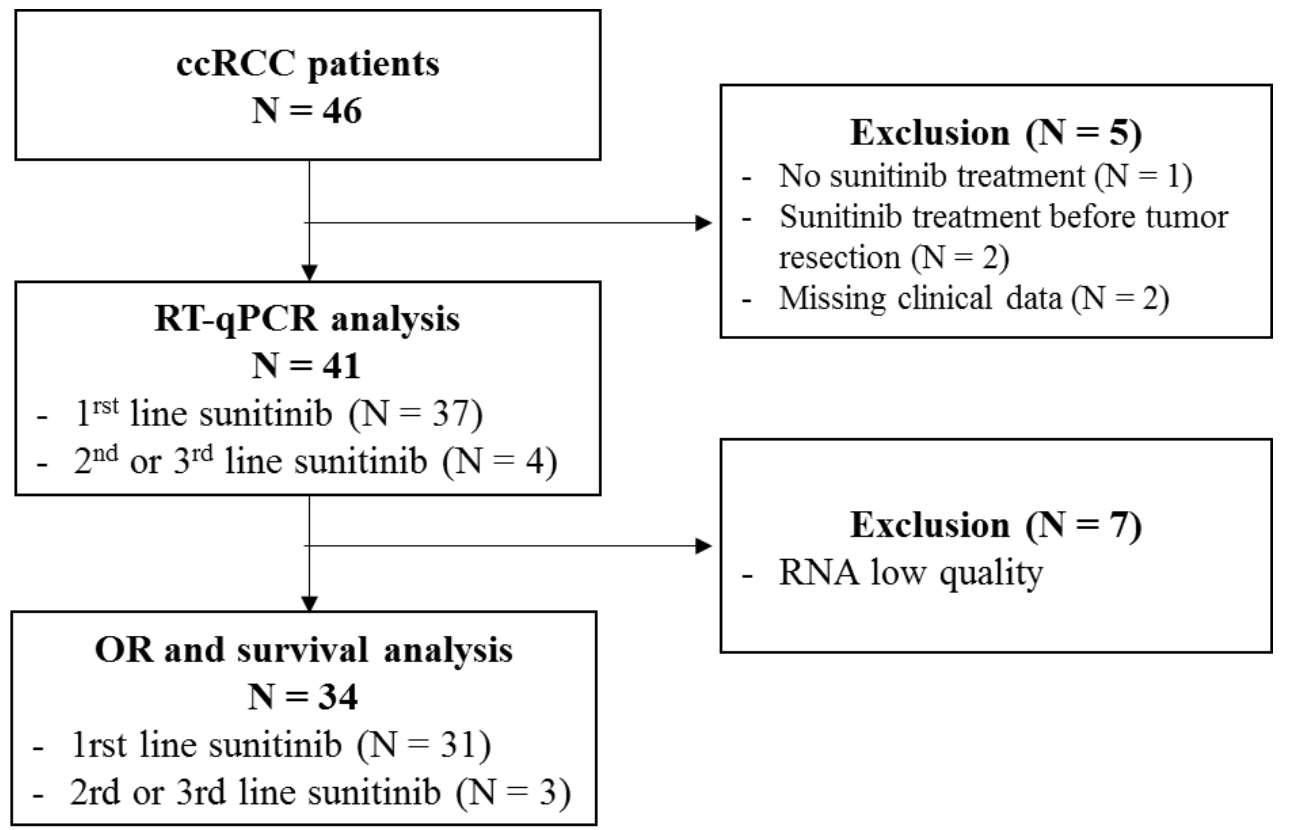

Figure 2: Flowchart of the study. 
medRxiv preprint doi: https://doi.org/10.1101/2021.11.10.21266155; this version posted November 10,2021 . The copyright holder for this preprint (which was not certified by peer review) is the author/funder, who has granted medRxiv a license to display the preprint in perpetuity.

Gene expression signature to predict the response to sunitinib in advanced ccRCC

\begin{tabular}{ll} 
Characteristic & $\mathbf{N}=\mathbf{3 4}$ \\
\hline $\begin{array}{l}\text { Median age (range) - years } \\
\text { Sex - no. }(\%)\end{array}$ & $66(51-85)$ \\
$\quad$ Male & $25(73.5 \%)$ \\
$\quad$ Female & $9(26.5 \%)$ \\
Metastases - no. (\%) & \\
$\quad$ Yes & $30(88.2 \%)$ \\
$\quad$ No & $4(11.8 \%)$ \\
Confirmed objective response rate - no. $(\%)$ & $7(20.6 \%)$ \\
Confirmed best overall response - no. $(\%)$ & \\
$\quad$ Complete response & $1(2.9 \%)$ \\
$\quad$ Partial response & $6(17.6 \%)$ \\
$\quad$ Stable disease & $18(52.9 \%)$ \\
$\quad$ Progressive disease & $9(26.5 \%)$ \\
Median follow-up (min - max) - months & $24.7(0.8-111.6)$ \\
Median progression-free survival (min - max) - months & $7.8(0.8-76.2)$ \\
Median overall survival (min - max) - months & $27.4(0.8-80.4)$ \\
VEGFR2 raw expression level (range) - $2^{\wedge}-\mathrm{dCt}$ X10^3 & $1.84(0.02-17.40)$ \\
\hline
\end{tabular}

Table 1: Baseline patient characteristics and clinical outcomes of all patients treated with sunitinib and included in the gene expression analysis $(\mathrm{N}=34)$

\subsection{VEGFR2-score and response to sunitinib}

VEGFR2-scores ranged between 2.0 and 1000.0, with a mean of 504.3. Six out of 7 patients with PR or CR had high VEGFR2score, and 18 out of 27 patients with PD or SD had low VEGFR2-score. It resulted in a sensitivity of $86 \%$, a specificity of $67 \%$, an AUC of $72.5 \%$ (95\%CI [50.1 - 94.9]; $\mathrm{p}=0.04$ ) (Fig. 3A,B). On the ten patients with the highest VEGFR2-scores, 1 had a complete response, 3 had partial responses and 6 had stable diseases. Conversely, low VEGFR2scores had a negative predictive value of 94.7\%. Raw VEGFR2 expression had poorer relation to response to sunitinib compared to PREDMED® VEGFR2-scores, with an AUC of $48.4 \%$ (95\%CI [25.2 - 71.6]; $\mathrm{p}=0.32)$, a sensitivity of $71 \%$ and a specificity of $56 \%$ (Fig. 3C,D).

\subsection{VEGFR2-scores and outcome under sunitinib}

We observed that PFS was significantly longer in patients with higher VEGFR2-scores (HR: 0.465, 95\%CI [0.221-0.978], $\mathrm{p}=0.0311$ ) (Fig. 4A). OS was also significantly longer in patients with higher VEGFR2-scores (HR: $0.400,95 \%$ CI [0.192-0.834], $\mathrm{p}=0.0134$ ) (Fig. 4B). The 5 patients who were still alive at the date of end of study - more than 77.2 months after the initiation of sunitinib - had very high VEGFR2-score (4 with 1000, 1 with 749). Among them, 2 patients with higest scores were still under sunitinib treatment, 81.4 and 92.9 months after initiation. Conversely, raw VEGFR2 mRNA expression was not significantly related to PFS and OS (for PFS, $\mathrm{HR}=0.682,95 \% \mathrm{CI}[0.323-1.438], \mathrm{p}=0.28$; and for OS, HR $=0.705,95 \%$ CI [0.338-1.470], $\mathrm{p}=0.33$ ) (Supplementary Figure 2). 


\section{VEGFR2-score and response to sunitinib}

$\mathbf{A}$

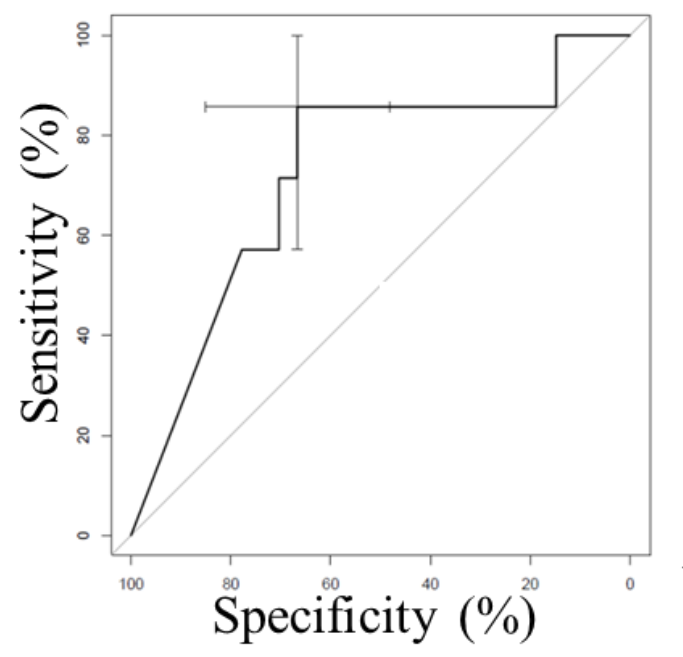

B

\begin{tabular}{|c|c|c|}
\hline $\mathrm{PR} / \mathrm{CR}$ & $\begin{array}{c}\mathrm{N}=6 \\
\text { Sensitivity } 86 \% \\
\end{array}$ & $\mathrm{~N}=1$ \\
\hline $\mathrm{SD} / \mathrm{PD}$ & $\mathrm{N}=9$ & $\begin{array}{c}N=18 \\
\text { Specificity } 67 \%\end{array}$ \\
\hline & $\begin{array}{c}\text { VEGFR2-score } \\
>637\end{array}$ & $\begin{array}{c}\text { VEGFR2-score } \\
<637\end{array}$ \\
\hline
\end{tabular}

AUC: $72.5 \%(50.1 \%-94.9 \%)$

\section{VEGFR2 raw expression and response to sunitinib}

C

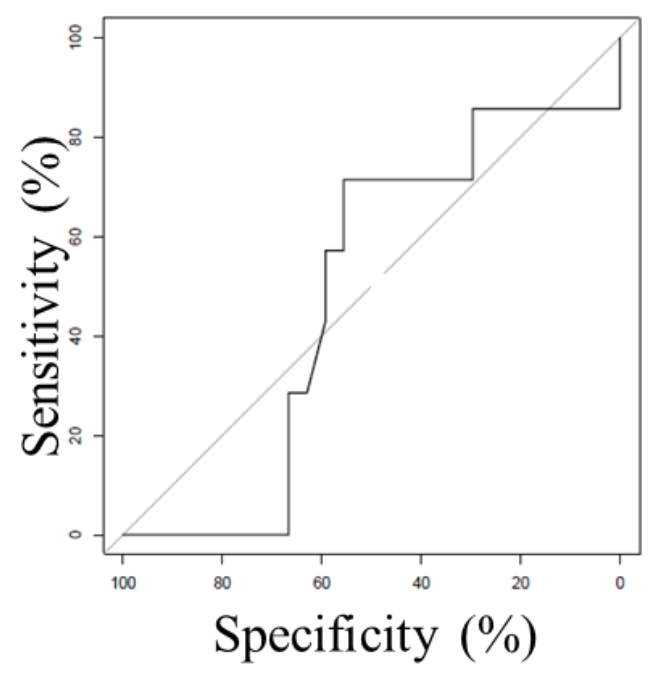

D

\begin{tabular}{c|c|c|}
\cline { 2 - 3 } PR/CR & $\begin{array}{c}\mathrm{N}=5 \\
\text { Sensitivity } 71 \%\end{array}$ & $\mathrm{~N}=2$ \\
\cline { 2 - 3 } SD/PD & $\mathrm{N}=12$ & $\begin{array}{c}\mathrm{N}=15 \\
\text { Specificity } 56 \%\end{array}$ \\
\cline { 2 - 2 } & VEGFR2 & VEGFR2 \\
expression & expression \\
$>0.79$ & $<0.79$
\end{tabular}

AUC: $48.4 \%$ (25.2\%-71.6\%)

$p=0.32$ (ns)

Figure 3: VEGFR2 and response to sunitinib. A, VEGFR2-score and response to sunitinib: ROC curve displaying the prediction performances of the VEGFR2-score computed using the PREDMED ${ }^{\circledR}$ signature algorithm. Area under the curve (AUC), 95\% confidence interval and associated p-value are indicated. B, Contingency table depicting the number of partial and complete responses (PR/CR) and stable and progressive diseases (SD/PD) accurately predicted using the VEGFR2-score with a cut-off at 637. C, VEGFR2 raw expression and response to sunitinib: ROC curve displaying the prediction performances of the VEGFR2 mRNA expression alone after normalization on housekeeping genes. Area under the curve (AUC), 95\% confidence interval and associated p-value are indicated. D, Contingency table depicting the number of partial and complete responses (PR/CR) and stable and progressive diseases (SD/PD) accurately predicted using the VEGFR2 mRNA expression with a cutoff at 0.79 . 
medRxiv preprint doi: https://doi.org/10.1101/2021.11.10.21266155; this version posted November 10, 2021. The copyright holder for this preprint (which was not certified by peer review) is the author/funder, who has granted medRxiv a license to display the preprint in

\section{VEGFR2-scores and outcome under sunitinib}
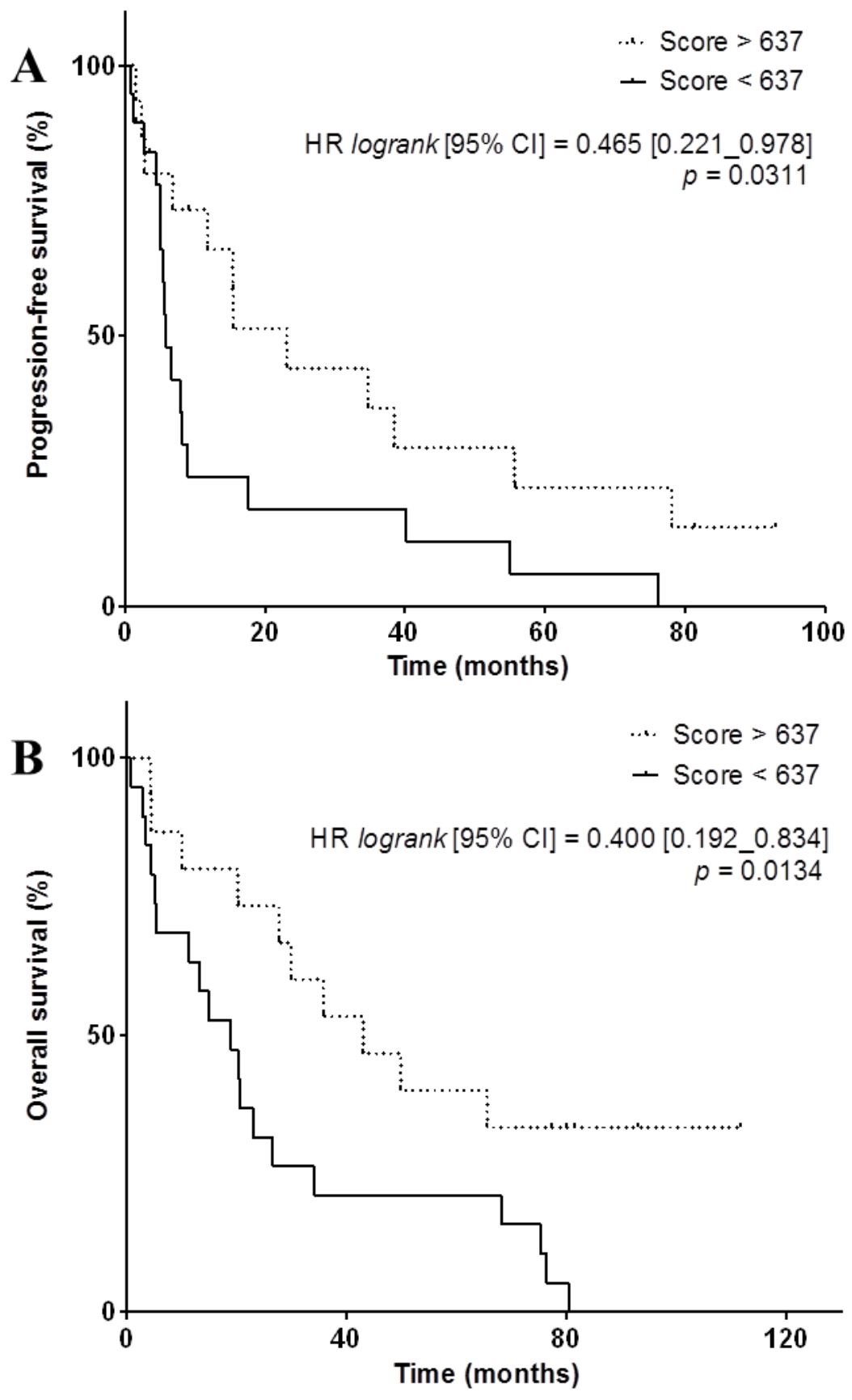

Figure 4: VEGFR2-scores and outcome under sunitinib. A,B, Kaplan-Meier analysis of progression-free survival (A) and overall survival (B) of patients with a high VEGFR2-score (> 637, dotted line) versus patients with a low VEGFR-score (<637, full line). Hazard ratio (logrank), 95\% confidence interval and associated $\mathrm{p}$-value are indicated. 


\section{DISCUSSION}

PREDMED ${ }^{\circledR}$ denoised the tumor expression of VEGFR2 by analyzing the tumor and normal kidney tissues and cell types of 37 gene expressions selected for their biological and therapeutic roles. For 34 patients with advanced of metastatic ccRCC who received sunitinib, VEGFR2-scores related to overall response rate, progression-free survival and overall survival. Six out of 7 patients who responded to sunitinib had a high VEGFR2score (sensitivity $86 \%$ ), 18 out of 27 patients with stable or progressive disease displayed a low VEGFR2-score (specificity 67\%). In addition, wrong negative prediction only occurred with one patient who showed partial response while displaying a low VEGFR2score (negative predictive value 94.7\%). It included patient in various treatment lines with sunitinib, independently from the prognosisrisk groups. Previous studies suggested that high VEGFR2 expression may reflect favorable outcome on sunitinib in patients with ccRCC, and therefore could be used as a predictive biomarker of response ${ }^{13,14,16,17}$. In our cohort, the raw VEGFR2 expression assessed by RT-qPCR failed to relate to the above mentioned outcomes.

Our study suggest that conventional gene expression analysis to drive targeted treatment relies may be limited by inherent noise. Noise may come from biological sampling, interindividual variation, or technical variation, among other factors. Denoising expression data from internal and/or external factors is not a usual approach. One of the few clinical evaluation of such hypothesis has been performed in the WINTHER study 23 (NCT01856296). WINTHER proposed transcriptomic analysis from tumor biospsies which were normalized on normal surounding tissue of various cancer types. Although the study did not meet its pre-specified primary end-point, it yielded promising outcome results in heavily pre-treated patients and confirmed that assessing the expression profile of tumor to guide treatment is feasible and do not delay therapeutic care. Our tool differs from the WINTHER algorithm through its iterative multi-normalization process and a large number of reference normal tissue gene expressions. It does not require the biopsy of healthy tissue from the patients to compute the score.

The present study is limited by its retrospective nature; thus, a prospective validation of our findings is planned through a noninterventional study on advanced ccRCC patients receiving sunitinib, We also consider evaluating this strategy for other ccRCCapproved antiangiogenics, in particular to define whether another antiangiogenic, such as pazopanib or axitinib, should be preferred over sunitinib or should be avoid as well in case of low VEGFR2-scoring. Another limitation of the study is the scarce clinical characteristics available in the database. We could not calculate the standard prognosis IMDC scores to investigate PREDMED ${ }^{\circledR}$ predictions within each risk-group of patients. Nevertheless, our approach shows that gene expression assessment from surgical samples can relate to outcome under sunitinib treatment when sophisticated normalization is performed. Finally, in the current study, we did not take into consideration the scores associated with other genes targeted by sunitinib, such as PDGFR or RET. Future multivariate development of the algorithm could allow more specific multi-kinase predictions.

Given the gene panel used and its potential versatility, PREDMED ${ }^{\circledR}$ test can address various therapeutic options, including targeted therapies and immunotherapies, in various tumor types. In this pilot study, the highest priority was given to advanced and metastatic ccRCC, as it remains one of the tumor types with the largest approved treatment options with no validated biomarker available. An additional attractive perspective concerns combinatorial strategies involving immunecheckpoint blockers with or without antiangiogenics in first-line setting, particularly in intermediate and high-risk patients. It is conceivable that a small - and yet unidentified - proportion of patients may benefit from an antiangiogenic added to the anti-PD(L)1 drug, and conversely, some patients may more benefit from a doublet of immune-checkpoint blockers. Importantly, some patients may also benefit from a monotherapy of antiangiogenic and be primarily resistant to immune-checkpoint 
medRxiv preprint doi: https://doi.org/10.1101/2021.11.10.21266155; this version posted November 10, 2021. The copyright holder for this preprint (which was not certified by peer review) is the author/funder, who has granted medRxiv a license to display the preprint in All rights reserved. No reusetuity. Gene expression signature to predict the response to sunitinib in advanced ccRCC

blockers ${ }^{11,12}$. Biomarkers are urgently needed to identify such a population; hence, to ease personalized decision making and to optimize therapeutic care for advanced and metastatic cancer patients. 
medRxiv preprint doi: https://doi.org/10.1101/2021.11.10.21266155; this version posted November 10, 2021. The copyright holder for this preprint (which was not certified by peer review) is the author/funder, who has granted medRxiv a license to display the preprint in

All rights reserved. No reuse allowed without permission.

\section{ACKNOWLEDGMENTS}

The authors thank the members of the UroCCR biological resources center (CRB-K) at Bordeaux, France. The authors are gratefull to Laurence Albiges for her advices and support for this work. The authors would like to thank Justine Fritz, Mathilde Baranger and Coralie Gianesini for their contribution to the data generation.

\section{CONFLICT OF INTEREST}

LV, DM, MS, LT, BL and DB report personal fees from Adaptherapy related to the submitted work.

LV reports grants from Bristol-Myers Squibb, non-personal fees from Servier and PierreFabre, outside of the submitted work.

LV, as part of the Drug Development Department (DITEP):

Principal/sub-Investigator of Clinical Trials for Abbvie, Adaptimmune, Aduro Biotech, Agios Pharmaceuticals, Amgen, Argen-X Bvba, Arno Therapeutics, Astex Pharmaceuticals, Astra Zeneca Ab, Aveo, Basilea Pharmaceutica International Ltd, Bayer Healthcare Ag, Bbb Technologies Bv, Beigene, Blueprint
Medicines, Boehringer Ingelheim, Boston Pharmaceuticals, Bristol Myers Squibb, Ca, Celgene Corporation, Chugai Pharmaceutical Co, Clovis Oncology, Cullinan-Apollo, Daiichi Sankyo, Debiopharm, Eisai, Eisai Limited, Eli Lilly, Exelixis, Faron Pharmaceuticals Ltd, Forma Tharapeutics, Gamamabs, Genentech, Glaxosmithkline, H3 Biomedicine, Hoffmann La Roche Ag, Imcheck Therapeutics, Innate Pharma, Institut De Recherche Pierre Fabre, Iris Servier, Janssen Cilag, Janssen Research Foundation, Kura Oncology, Kyowa Kirin Pharm. Dev, Lilly France, Loxo Oncology, Lytix Biopharma As, Medimmune, Menarini Ricerche, Merck Sharp \& Dohme Chibret, Merrimack Pharmaceuticals, Merus, Millennium Pharmaceuticals, Molecular Partners Ag, Nanobiotix, Nektar Therapeutics, Novartis Pharma, Octimet Oncology Nv, Oncoethix, Oncopeptides, Orion Pharma, Ose Pharma, Pfizer, Pharma Mar, Pierre Fabre, Medicament, Roche, Sanofi Aventis, Seattle Genetics, Sotio A.S, Syros Pharmaceuticals, Taiho Pharma, Tesaro, Xencor. Research Grants from Astrazeneca, BMS, Boehringer Ingelheim, Janssen Cilag, Merck, Novartis, Onxeo, Pfizer, Roche, Sanofi. Non-financial support (drug supplied) from Astrazeneca, Bayer, BMS, Boringher Ingelheim, Medimmune, Merck, NH TherAGuiX, Onxeo, Pfizer, Roche.

The other authors have no conflict of interest to declare. 
medRxiv preprint doi: https://doi.org/10.1101/2021.11.10.21266155; this version posted November 10, 2021. The copyright holder for this

preprint (which was not certified by peer review) is the author/funder, who has granted medRxiv a license to display the preprint in

perpetuity.

Gene expression signature to predict the response to sunitinib in advanced ccRCC

\section{REFERENCES}

1. Udager, A. M. \& Mehra, R. Morphologic, Molecular, and Taxonomic Evolution of Renal Cell Carcinoma: A Conceptual Perspective With Emphasis on Updates to the 2016 World Health Organization Classification. Arch. Pathol. Lab. Med. 140, 1026-1037 (2016).

2. The Cancer Genome Atlas Research Network. Comprehensive molecular characterization of clear cell renal cell carcinoma. Nature 499, 43-49 (2013).

3. Turajlic, S. et al. Deterministic Evolutionary Trajectories Influence Primary Tumor Growth: TRACERx Renal. Cell 173, 595-610.e11 (2018).

4. Latif, F. et al. Identification of the von Hippel-Lindau disease tumor suppressor gene. Science 260, 1317-1320 (1993).

5. Baldewijns, M. M. et al. VHL and HIF signalling in renal cell carcinogenesis. J. Pathol. 221, 125-138 (2010).

6. Chow, W.-H., Dong, L. M. \& Devesa, S. S. Epidemiology and risk factors for kidney cancer. Nat. Rev. Urol. 7, 245-257 (2010).

7. Escudier, B. et al. Renal cell carcinoma: ESMO Clinical Practice Guidelines for diagnosis, treatment and follow-up†. Ann. Oncol. 30, 706-720 (2019).

8. Heng, D. Y. C. et al. Prognostic Factors for Overall Survival in Patients With Metastatic Renal Cell Carcinoma Treated With Vascular Endothelial Growth Factor-Targeted Agents: Results From a Large, Multicenter Study. J. Clin. Oncol. 27, 5794-5799 (2009).

9. Motzer, R. J. et al. Nivolumab plus Ipilimumab versus Sunitinib in Advanced Renal-Cell Carcinoma. N. Engl. J. Med. 378, 1277-1290 (2018).

10. Rini, B. I. et al. Pembrolizumab plus Axitinib versus Sunitinib for Advanced Renal-Cell Carcinoma. N. Engl. J. Med. 380, 1116-1127 (2019).

11. Liu, X.-D. et al. PBRM1 loss defines a nonimmunogenic tumor phenotype associated with checkpoint inhibitor resistance in renal carcinoma. Nat. Commun. 11, 2135 (2020).

12. McDermott, D. F. et al. Clinical activity and molecular correlates of response to atezolizumab alone or in combination with bevacizumab versus sunitinib in renal cell carcinoma. Nat. Med. 24, 749-757 (2018).

13. DePrimo, S. E. et al. Circulating protein biomarkers of pharmacodynamic activity of sunitinib in patients with metastatic renal cell carcinoma: modulation of VEGF and VEGF-related proteins. $J$. Transl. Med. 5, (2007).

14. del Puerto-Nevado, L. et al. Active angiogenesis in metastatic renal cell carcinoma predicts clinical benefit to sunitinib-based therapy. Br. J. Cancer 110, 2700-2707 (2014).

15. Choueiri, T. K. et al. The Role of Aberrant VHL/HIF Pathway Elements in Predicting Clinical Outcome to Pazopanib Therapy in Patients with Metastatic Clear-Cell Renal Cell Carcinoma. Clin. Cancer Res. 19, 5218-5226 (2013).

16. Beuselinck, B. et al. Pro-angiogenic gene expression is associated with better outcome on sunitinib in metastatic clear-cell renal cell carcinoma. Acta Oncol. 57, 498-508 (2018).

17. Terakawa, T., Miyake, H., Kusuda, Y. \& Fujisawa, M. Expression level of vascular endothelial growth factor receptor-2 in radical nephrectomy specimens as a prognostic predictor in patients with metastatic renal cell carcinoma treated with sunitinib. Urol. Oncol. Semin. Orig. Investig. 31, 493-498 (2013).

18. del Puerto-Nevado, L. et al. Active angiogenesis in metastatic renal cell carcinoma predicts clinical benefit to sunitinib-based therapy. Br. J. Cancer 110, 2700-2707 (2014).

19. Eisenhauer, E. A. et al. New response evaluation criteria in solid tumours: Revised RECIST guideline (version 1.1). Eur. J. Cancer 45, 228-247 (2009).

20. Cohen, J. F. et al. STARD 2015 guidelines for reporting diagnostic accuracy studies: explanation and elaboration. BMJ Open 6, e012799 (2016).

21. Fritz, J., Lefebvre, O., Fernandez, A., Schmidt, J. \& Bagnard, D. Prediction of Drug Efficacy in Colon Cancer Preclinical Models Using a Novel Ranking Method of Gene Expression. Cancers 12, (2020).

22. Plummer, M. JAGS: A Program for Analysis of Bayesian Graphical Models using Gibbs Sampling. 3rd Int. Workshop Distrib. Stat. Comput. DSC 2003 Vienna Austria 124, (2003).

23. Rodon, J. et al. Genomic and transcriptomic profiling expands precision cancer medicine: the WINTHER trial. Nat. Med. 25, 751-758 (2019). 
medRxiv preprint doi: https://doi.org/10.1101/2021.11.10.21266155; this version posted November 10, 2021. The copyright holder for this preprint (which was not certified by peer review) is the author/funder, who has granted medRxiv a license to display the preprint in All rights reserved. No reuse allowed

Gene expression signature to predict the response to sunitinib in advanced ccRCC

\section{SUPPLEMENTARY FIGURES}

\begin{tabular}{|c|c|}
\hline Assay ID/Name & Target Gene Name \\
\hline Hs99999901_s1 & $18 S$ \\
\hline Hs00153350_m1 & BCL2 \\
\hline Hs00164982_m1 & JAG1 \\
\hline Hs00171172_m1 & AR \\
\hline Hs00173626_m1 & VEGFA \\
\hline Hs00176538_m1 & ERBB3 \\
\hline Hs00176607_m1 & FLT4 \\
\hline Hs00178289_m1 & AKT1 \\
\hline Hs00179829_m1 & FGFR3 \\
\hline Hs00183486_m1 & PDGFRA \\
\hline Hs00231032_m1 & HDAC2 \\
\hline Hs00234119_m1 & RAF1 \\
\hline \begin{tabular}{|l|} 
Hs00269944_m1 \\
\end{tabular} & BRAF \\
\hline \begin{tabular}{|l|}
$H s 00360958$ g1 \\
\end{tabular} & MAP2K2 \\
\hline Hs00431459_m1 & KIR2DL5A;KIR2DL5B \\
\hline Hs00608291_m1 & ALK \\
\hline Hs00609566_m1 & IGF1R \\
\hline Hs00911700_m1 & KDR \\
\hline Hs00915142_m1 & FGFR1 \\
\hline \begin{tabular}{|l|} 
Hs00933163_m1 \\
\end{tabular} & PIK3R1 \\
\hline Hs00936368_m1 & HIF1A \\
\hline Hs00957562_m1 & MMP9 \\
\hline Hs00983247_g1 & MAP2K1 \\
\hline Hs01001580_m1 & ERBB2 \\
\hline Hs01009250_m1 & PROM1 \\
\hline Hs01019589_m1 & PDGFRB \\
\hline Hs01026371_m1 & CDK6 \\
\hline Hs01066930_m1 & MDM2 \\
\hline \begin{tabular}{|l|} 
Hs01076078_m1 \\
\end{tabular} & EGFR \\
\hline Hs01104728_m1 & $\mathrm{ABL} 1$ \\
\hline Hs01120030_m1 & RET \\
\hline Hs01547673_m1 & ITGA5 \\
\hline Hs01552926_m1 & FGFR2 \\
\hline Hs01565583_m1 & MET \\
\hline \begin{tabular}{|l|} 
Hs01565683_g1 \\
\end{tabular} & CDK4 \\
\hline Hs02621185_s1 & HDAC1 \\
\hline Hs99999905_m1 & GAPDH \\
\hline
\end{tabular}

\section{Supplementary}

figure 1: List of the targeted genes evaluated by RT-qPCR to enrich the algorithm and corresponding primer 
medRxiv preprint doi: https://doi.org/10.1101/2021.11.10.21266155; this version posted November 10, 2021. The copyright holder for this preprint (which was not certified by peer review) is the author/funder, who has granted medRxiv a license to display the preprint in All rights reserved. No reusetuity.

Gene expression signature to predict the response to sunitinib in advanced ccRCC

A

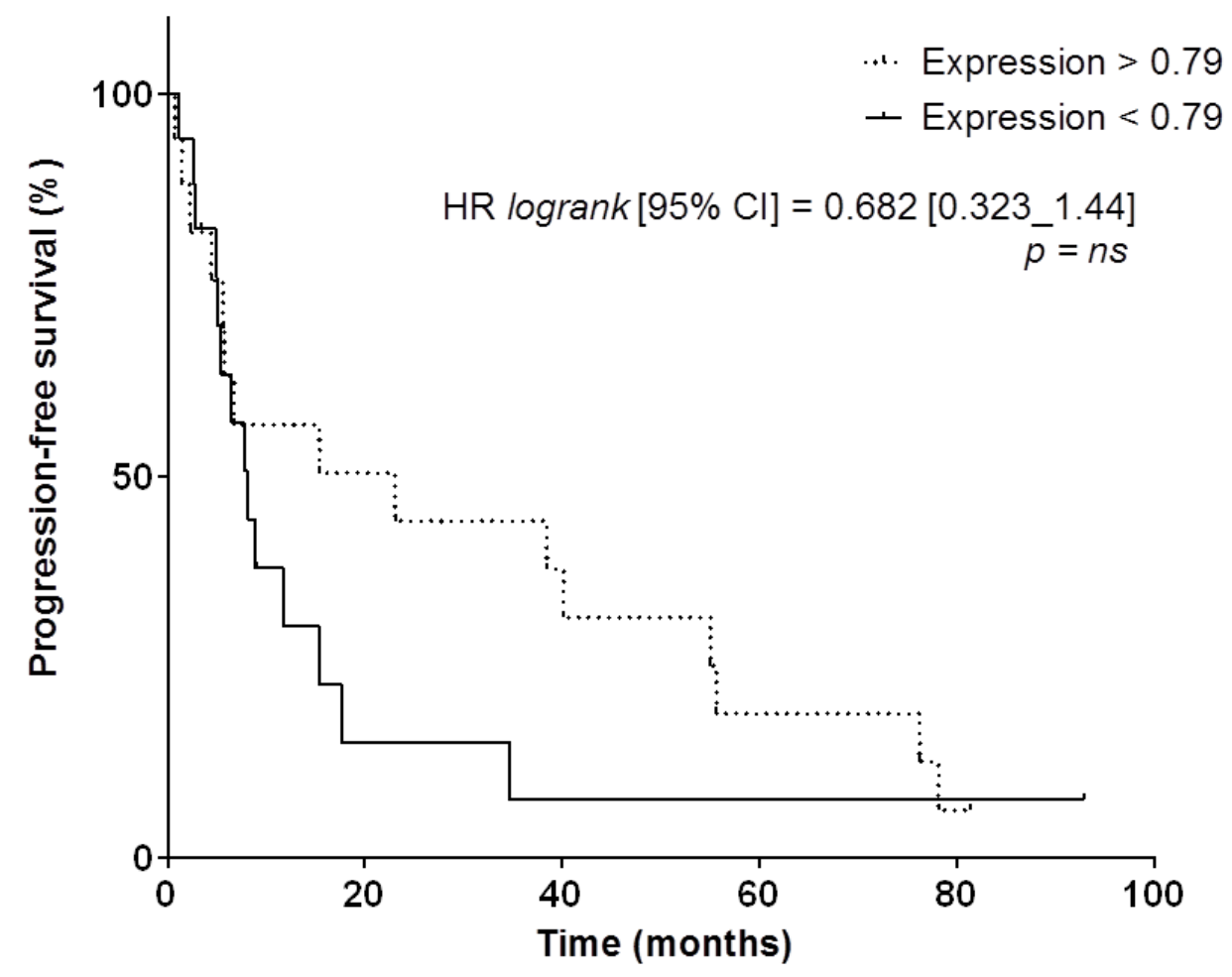

B

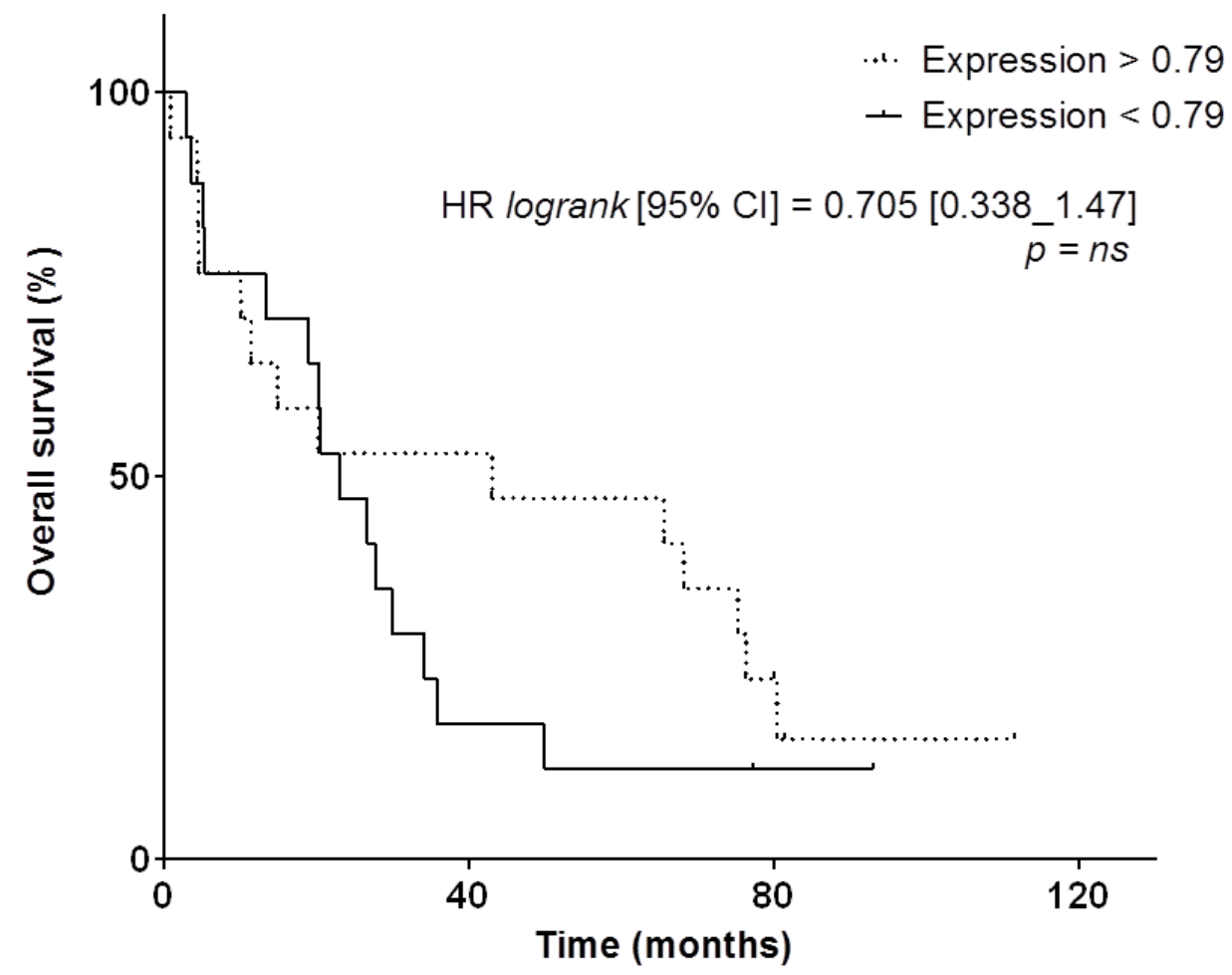

IDs.Supplementary figure 2: A,B, Kaplan-Meier analysis of progression-free survival (A) and overall survival (B) of patients displaying a high VEGFR2 mRNA expression (>0.79, dotted line) versus patients displaying a low VEGFR2 mRNA expression $(<0.79$, full line). Hazard ratio (logrank), 95\% confidence interval and associated p-value are indicated. 